\title{
Polypyridyl iron(II) complexes showing remarkable photocytotoxicity in visible light
}

\author{
ADITYA GARAI ${ }^{\mathrm{a}}$, UTTARA BASU ${ }^{\mathrm{a}}$, ILA PANT ${ }^{\mathrm{b}}$, PATURU KONDAIAH $^{\mathrm{b}, *}$ \\ and AKHIL R CHAKRAVARTY ${ }^{\mathrm{a}, *}$ \\ ${ }^{a}$ Department of Inorganic and Physical Chemistry, Indian Institute of Science, Bangalore 560012, India \\ ${ }^{\mathrm{b}}$ Department of Molecular Reproduction, Development and Genetics, Indian Institute of Science, \\ Bangalore 560012, India \\ e-mail: paturu@mrdg.iisc.ernet.in; arc@ipc.iisc.ernet.in
}

MS received 11 October 2014; revised 17 November 2014; accepted 22 November 2014

\begin{abstract}
Iron(II) complexes of polypyridyl ligands (B), viz. [Fe(B) $\left.)_{2}\right] \mathrm{Cl}_{2}(\mathbf{1}$ and $\mathbf{2})$ of $N, N, N$-donor 2-(2pyridyl)-1,10-phenanthroline (pyphen in 1) and 3-(pyridin-2-yl)dipyrido[3,2-a:2',3'-c]phenazine (pydppz in 2), are prepared and characterized. They are 1:2 electrolytes in aqueous DMF. The diamagnetic complexes exhibit metal to ligand charge transfer band near $570 \mathrm{~nm}$ in DMF. The complexes are avid binders to calf thymus DNA giving binding constant $\left(K_{\mathrm{b}}\right)$ values of $\sim 10^{6} \mathrm{M}^{-1}$ suggesting significant intercalative DNA binding of the complexes due to presence of planar phenanthroline bases. Complex $\mathbf{2}$ exhibits significant photocytotoxicity in immortalized human keratinocyte cells $\mathrm{HaCaT}$ and breast cancer cell line MCF-7 giving $\mathrm{IC}_{50}$ values of 0.08 and $13 \mu \mathrm{M}$ in visible light $(400-700 \mathrm{~nm})$. Complex 2 shows only minor dark toxicity in HaCaT cells but is non-toxic in dark in MCF-7 cancer cells. The light-induced cellular damage follows apoptotic pathway on generation of reactive oxygen species as evidenced from the dichlorofluorescein diacetate (DCFDA) assay.
\end{abstract}

Keywords. Iron; polypyridyl bases; DNA binding; photocytotoxicity; apoptosis.

\section{Introduction}

Photodynamic therapy (PDT) involves selective targeting and damaging cancer cells leaving unexposed healthy cells unaffected by photo-activating a drug in the tumour cells with visible or near IR light. ${ }^{1-5}$ Porphyrins and phthalocyanines are extensively studied for their photocytotoxic activity resulting from generation of singlet oxygen $\left({ }^{1} \mathrm{O}_{2}\right)$ as the reactive oxygen species (ROS) in a type-II energy transfer pathway involving the ${ }^{3}\left(\pi-\pi^{*}\right)$ state of the drug and molecular oxygen in its triplet ground state $\left({ }^{3} \mathrm{O}_{2}\right){ }^{6,7}$ The efficacy of these PDT agents depends primarily on the quantum yield of singlet oxygen generation and Photofrin ${ }^{\circledR}$ is currently known as the FDA approved PDT drug. The porphyrin bases generally show skin photosensitivity and hepatotoxicity thus significantly limiting their therapeutic potential. ${ }^{8,9}$ These predicaments have generated interests to develop the chemistry of metal-based PDT agents as suitable alternatives to Photofrin. ${ }^{10-20}$ Metal complexes could show photocytotoxicity via different mechanistic pathways that include type-I and/or photo-redox pathway forming superoxide or hydroxyl radicals as the ROS besides having

\footnotetext{
*For correspondence
}

the type-II ${ }^{1} \mathrm{O}_{2}$ pathway. ${ }^{7}$ We have recently reported iron(III) and oxovanadium(IV) complexes as potential 3d metal-based PDT agents displaying significant lightinduced cytotoxicity. ${ }^{21-23}$ Metal-based PDT agents are thus emerging as new generation anti-cancer agents along with several recent advancements on platinum based chemotherapeutic and photo-chemotherapeutic agents. $^{24-26}$ The present work stems from our interests to develop iron-based photocytotoxic agents considering the bio-essential nature of iron and its important redox and photophysical chemistry. Bleomycins (BLMs) are the iron-based natural anti-tumour agents which show oxidative damage of DNA in cancer cells forming cytotoxic hydroxyl radicals. ${ }^{27,28}$

Iron complexes with the metal in its +3 oxidation state are prone to reduction inside the cells by cellular reducing agents like glutathione (GSH). Iron(III) complexes having azide ligand are known to show significant DNA photocleavage activity. ${ }^{29}$ We have reported a high spin $(S=5 / 2)$ ternary iron(III) complex $[\mathrm{Fe}(\mathrm{BHA})(\mathrm{L}) \mathrm{Cl}]$ of a dipicolylamine derivative $(\mathrm{L})$ and benzhydroxamic acid (HBHA) which shows photocytotoxicity giving an $\mathrm{IC}_{50}$ value of $14.6 \mu \mathrm{M}$ upon irradiation with a visible light $(400-700 \mathrm{~nm})$ in HeLa cancer cells. ${ }^{30}$ The iron(III) complexes are susceptible to show undesired chemical nuclease activity due to in situ 
generation of reactive iron(II) species by GSH. In contrast, the metal in its stable diamagnetic +2 oxidation state is expected to have low dark toxicity. We have thus designed low-spin iron(II) complexes as a new class of photocytotoxic agents in visible light using polypyridyl ligands that could stabilize the metal in its lower oxidation state. There are few reports on iron(II) complexes modelling the biological activity of bleomycins (BLMs). ${ }^{31-34}$ High spin ( $\mathrm{S}=2$ ) iron(II) complexes having pentadentate polypyridyl ligands are known to show cytotoxicity in dark giving $\mathrm{IC}_{50}$ values of 1.1 to 7.7 $\mu \mathrm{M}$ in various cancer cell lines. ${ }^{31}$ The iron(II) complexes showing the BLM activity are generally not suitable for PDT application as the primary requirement of a PDT agent is that the complex must be less or non-toxic in dark while being highly photocytotoxic in visible light. Keeping that in mind, we have prepared two iron(II) complexes, viz. $\left[\mathrm{Fe}(\mathrm{B})_{2}\right] \mathrm{Cl}_{2}$ (1 and 2) of $N, N, N$-donor 2-(2-pyridyl)-1,10-phenanthroline (pyphen in 1) and 3-(pyridin-2-yl)dipyrido[3,2-a:2',3'c]phenazine (pydppz in 2) and the complexes show significant photo-induced cytotoxicity in immortal human keratinocyte cell line $\mathrm{HaCaT}$ and breast cancer cell line MCF-7 (figure 1).

\section{Experimental}

\subsection{Materials and methods}

All the reagents and chemicals were procured from commercial sources (SD Fine Chemicals, India;

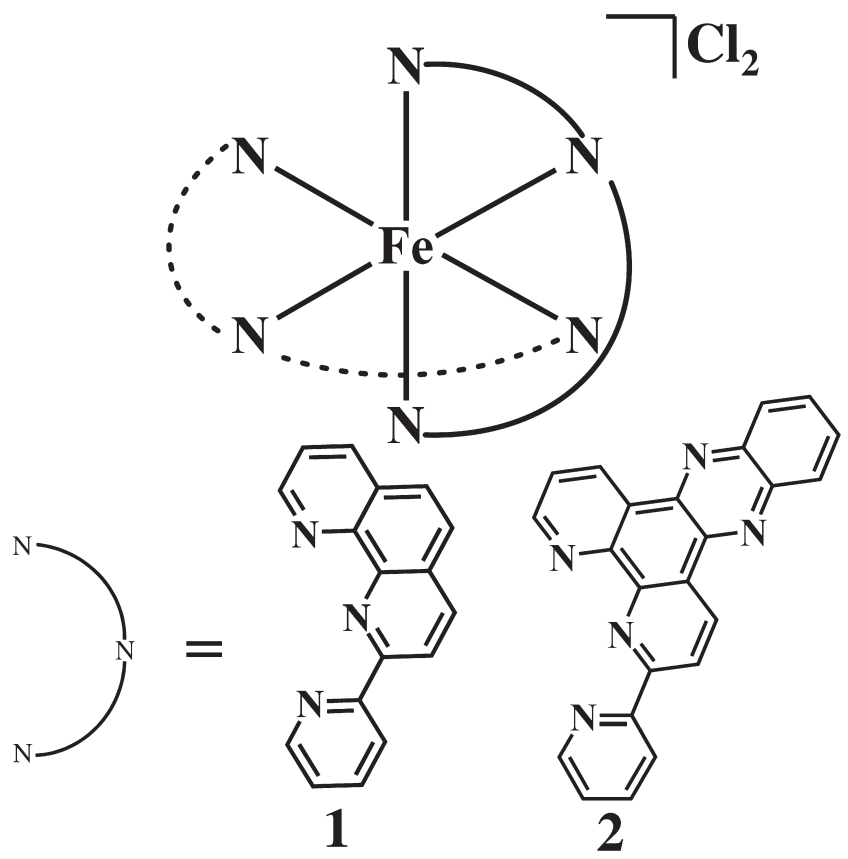

Figure 1. Schematic representation of the polypyridyl bases and complexes $\mathbf{1}$ and $\mathbf{2}$.
Aldrich, USA) and used without any further purification. Solvents used were purified by standard procedures. ${ }^{35}$ Calf thymus (ct) DNA, ethidium bromide (EB), Hoechst 33258, 2' ,7'-dichlorofluoresceindiacetate (DCFDA), 3-(4,5-dimethylthiazol-2-yl)-2,5-diphenyltetrazolium bromide (MTT), propidium iodide (PI), acridine orange (AO), Dulbecco's modified eagle medium (DMEM), Dulbecco's phosphate buffered saline (DPBS) and fetal bovine serum (FBS) were purchased from Sigma, USA. Tris-(hydroxymethyl)aminomethane- $\mathrm{HCl}$ (Tris-HCl) buffer solution was prepared using deionized and sonicated triple distilled water using a quartz water distillation setup. The $N, N, N$ donor heterocyclic bases 2-(2-pyridyl)-1,10-phenanthroline (pyphen) and 3-(pyridin-2-yl)dipyrido[3,2-a: 2',3'-c]phenazine (pydppz) were prepared following literature procedures. ${ }^{36-38}$

The elemental analyses were done using a Thermo Finnigan Flash EA 1112 CHNS analyzer. The infrared spectra were recorded on a Bruker ALPHA FT-IR spectrometer. Electronic spectra were obtained on a PerkinElmer Lambda 650 spectrophotometer. Molar conductivity measurements were carried out using a Control Dynamics (India) conductivity meter. Electrospray ionization mass spectra (ESI-MS) were recorded using Bruker Daltonics make Esquire 300 Plus ESI Model. ${ }^{1} \mathrm{H}$ NMR spectra were recorded at room temperature on a Bruker $400 \mathrm{MHz}$ NMR spectrometer. Flow cytometry (FACS) measurements were done using Calibur (Becton Dickinson (BD) cell analyzer) at FL1 channel. Imaging studies were done with Zeiss LSM510 apochromat confocal laser scanning microscope.

\subsection{Synthesis of the complexes}

Complexes $\mathbf{1}$ and $\mathbf{2}$ were prepared by following a general synthetic procedure in which a methanol solution $(25 \mathrm{~mL})$ of the respective base $(0.514 \mathrm{~g}$, pyphen; $0.718 \mathrm{~g}$, pydppz; $2.0 \mathrm{mmol}$ ) was added dropwise to a methanol solution $(25 \mathrm{~mL})$ of $\mathrm{FeCl}_{2}(0.125 \mathrm{~g} ; 1.0$ $\mathrm{mmol}$ ). Stirring of the reaction mixture for $30 \mathrm{~min}$ gave a deep purple coloured solution. The solvent was evaporated and the residue was washed with cold ethanol followed by cold diethyl ether, and finally dried in vacuum over $\mathrm{P}_{4} \mathrm{O}_{10}$. The characterization data for the complexes are given below.

2.2a $\left[\mathrm{Fe}(\text { pyphen })_{2}\right] \mathrm{Cl}_{2}(\mathbf{1})$ : [Yield: $0.54 \mathrm{~g}, \quad 85 \%$ ] Analysis: Calculated for $\mathrm{C}_{34} \mathrm{H}_{22} \mathrm{Cl}_{2} \mathrm{FeN}_{6}: \mathrm{C}, 63.68 ; \mathrm{H}$, 3.46; N, 13.10. Found: C, 63.53; H, 3.62; N, 12.98. ESIMS in $10 \%$ aqueous MeOH: $m / z 285.42[\mathrm{M}-2 \mathrm{Cl}]^{2+}$. IR / $\mathrm{cm}^{-1}$ : 2960w, 2911w, 1735w, 1607m, 1440vs, 1382vs, 
$1254 \mathrm{~s}, 1195 \mathrm{w}, 1100 \mathrm{~m}, 1000 \mathrm{~m}, 843 \mathrm{vs}, 730 \mathrm{~m}$, (vs, very strong; s, strong; m, medium; w, weak). UV-visible in DMF $\left[\lambda_{\max } / \mathrm{nm}\left(\varepsilon / \mathrm{M}^{-1} \mathrm{~cm}^{-1}\right)\right]: 580$ (5200), 484sh (4490), 347 (17290), 304 (34440) (sh, shoulder). Conductivity in $20 \%$ aqueous $\operatorname{DMF}\left(\Lambda_{\mathrm{M}}\right): 145 \mathrm{~S} \mathrm{~cm}^{2} \mathrm{M}^{-1}$.

2.2b [Fe(pydppz $\left.)_{2}\right] \mathrm{Cl}_{2}(2)$ : [Yield: $0.76 \mathrm{~g}, \quad 90 \%$ ] Analysis: Calculated for $\mathrm{C}_{46} \mathrm{H}_{26} \mathrm{Cl}_{2} \mathrm{FeN}_{10}$ : C, 65.34; $\mathrm{H}$, 3.10 ; N, 16.57. Found: C, 65.67; H, 3.31; N, 16.55. ESIMS in $10 \%$ aqueous $\mathrm{MeOH}: m / z 387.63[\mathrm{M}-2 \mathrm{Cl}]^{2+}$. IR $/ \mathrm{cm}^{-1}$ : 3045w, 2912w, 1607s, 1539w, 1480w, 1401s, $1343 \mathrm{vs}, 1254 \mathrm{~m}, 1118 \mathrm{~m}, 1041 \mathrm{~m}, 725 \mathrm{~s}, 590 \mathrm{w}$. UVvisible in DMF $\left[\lambda_{\max } / \mathrm{nm}\left(\varepsilon / \mathrm{M}^{-1} \mathrm{~cm}^{-1}\right)\right]: 556(4250)$, $388 \mathrm{sh}$ (20740), 367 (30690), 289 (62320). Conductivity in $20 \%$ aqueous $\operatorname{DMF}\left(\Lambda_{\mathrm{M}}\right): 142 \mathrm{~S} \mathrm{~cm}^{2} \mathrm{M}^{-1}$.

\subsection{Theoretical studies}

The geometry of the complexes $\mathbf{1}$ and $\mathbf{2}$ was optimized by density functional theory (DFT) method using B3LYP/LanLD2Z level as implemented in Gaussian 09 program. The electronic transitions with their transition probability were obtained using linear response time dependent density functional theory (TDDFT).

\subsection{DNA binding}

DNA binding experiments were done in Tris- $\mathrm{HCl} / \mathrm{NaCl}$ buffer ( $5 \mathrm{mM}$ Tris-HCl, $5 \mathrm{mM} \mathrm{NaCl}, \mathrm{pH}$ 7.2) using DMF solution of the complexes $\mathbf{1}$ and $\mathbf{2}$. Calf thymus (ct) DNA (ca. $250 \mu \mathrm{M} \mathrm{NP}$ ) in the buffer medium gave a UV absorbance ratio of ca. 1.9:1 at 260 and 280 $\mathrm{nm}$ indicating that the DNA is apparently free from any protein impurity. The concentration of ct-DNA was estimated from its absorption intensity at $260 \mathrm{~nm}$ with a known molar extinction coefficient value $(\varepsilon)$ of $6600 \mathrm{M}^{-1} \mathrm{~cm}^{-1}$. ${ }^{39}$ The absorption titration experiments were done by procedures as described. ${ }^{6}$ The intrinsic equilibrium binding constant $\left(K_{\mathrm{b}}\right)$ and the $\mathrm{MvH}$ equation fitting parameter $(s)$ of $\mathbf{1}$ and $\mathbf{2}$ to ct-DNA were obtained by McGhee-von Hippel $(\mathrm{MvH})$ method using the expression of Bard and co-workers by monitoring the change of the absorption intensity of the spectral bands with increasing concentration of ct-DNA. ${ }^{40,41}$

DNA melting experiments were carried out by monitoring the absorbance of ct-DNA $(200 \mu \mathrm{M})$ at $260 \mathrm{~nm}$ at various temperatures, both in the absence and presence of the complexes $(25 \mu \mathrm{M})$. Measurements were carried out using a Perkin-Elmer Lambda 650 spectrometer with a temperature controller at an increase rate of $0.5^{\circ} \mathrm{C}$ per min of the solution. Ethidium bromide (EB) was used as a control. Viscometric titrations were performed with a Schott Gerate AVS 310 automated viscometer that was maintained at $37^{\circ} \mathrm{C}$ in a constant temperature bath. The concentration of ct-DNA was $150 \mu \mathrm{M}$ in NP (nucleotide pair) and the flow times were measured using an automated timer. Each sample was measured 3 times and an average flow time was calculated. Data were presented as $\left(\eta / \eta_{0}\right)^{1 / 3} v s$. [complex]/[DNA], where $\eta$ is the viscosity of DNA in the presence of complex and $\eta_{0}$ is that of DNA alone. Viscosity values were calculated from the observed flow time of DNA-containing solutions $(t)$ corrected for that of the buffer alone $\left(t_{0}\right), \eta=\left(t-t_{0}\right) / t_{0}$. Due corrections were made for the viscosity of DMF solvent present in the solution.

\subsection{Cytotoxicity measurements by MTT assay}

The cytotoxicity of the complexes was studied using MTT assay in light and dark. This method is based on the ability of mitochondrial dehydrogenases of viable cells to cleave the tetrazolium rings of MTT, forming dark purple membrane impermeable crystals of formazan that can be estimated from the spectral measurements in DMSO. ${ }^{42}$ Approximately, 8000 cells (human immortalized keratinocytes $\mathrm{HaCaT}$ cells and breast cancer MCF-7cell line) were plated separately in a 96 wells culture plate in Dulbecco's Modified Eagle Medium (DMEM) containing 10\% FBS. After $24 \mathrm{~h}$ of incubation at $37^{\circ} \mathrm{C}$ in $5 \% \mathrm{CO}_{2}$ atmosphere, various concentrations of the complexes dissolved in $1 \%$ DMSO were added to the cells, and incubation was continued for $4 \mathrm{~h}$ in dark. The media was subsequently replaced with DPBS and irradiated with a broad band visible light (400-700 $\mathrm{nm}, 10 \mathrm{~J} \mathrm{~cm}^{-2}$ ), using a Luzchem Photoreactor (Model LZC-1, Ontario, Canada). After irradiation, DPBS was removed and replaced with DMEM/FBS, and incubation was continued for a further period of $20 \mathrm{~h}$ in dark. After the incubation period, $5 \mathrm{mg} \mathrm{mL} \mathrm{m}^{-1}$ of MTT (20 $\mu \mathrm{L}$ ) was added to each well and incubation continued for an additional $3 \mathrm{~h}$. The culture medium was discarded and $200 \mu \mathrm{L}$ of DMSO was added to dissolve the formazan crystals. The absorbance was measured at 540 nm using a Molecular Devices Spectra Max M5 plate reader. Cytotoxicity of the complexes was measured as the percentage ratio of the absorbance of the treated cells to the untreated controls. The $\mathrm{IC}_{50}$ values were determined by nonlinear regression analysis (GraphPad Prism 5).

\subsection{DCFDA assay for ROS generation}

DCFDA was used to detect the generation of any cellular ROS. ${ }^{43}$ Cell permeable DCFDA can be oxidized by cellular ROS to generate fluorescent $2^{\prime}, 7^{\prime}$-dichlo- 
rofluorescein (DCF) with an emission maxima at 525 $\mathrm{nm} .{ }^{44} \mathrm{MCF}-7$ cells were incubated with the complexes $1(60 \mu \mathrm{M})$ and $2(5 \mu \mathrm{M})$ for $4 \mathrm{~h}$ followed by irradiation with visible light $(400-700 \mathrm{~nm})$ for $1 \mathrm{~h}$ in DPBS. Cells treated with complexes $\mathbf{1}$ and $\mathbf{2}$ in dark were used as controls. The cells were harvested by trypsinization and washed with DPBS. A single cell suspension of $1 \times 10^{6}$ cells per $\mathrm{mL}$ was made and treated with $1 \mu \mathrm{M}$ DCFDA solution in dark for 15-20 min at $25^{\circ} \mathrm{C}$. The distribution of DCFDA stained MCF-7 cells was determined by flow cytometry in the FL-1 channel.

\subsection{Cell cycle analysis}

To investigate the effect of the complexes on the cell cycle, $3 \times 10^{6} \mathrm{MCF}-7$ cells were plated per well of a 6 wells tissue culture plate in DMEM containing $10 \%$ FBS. After $24 \mathrm{~h}$ of incubation at $37^{\circ} \mathrm{C}$ in a $\mathrm{CO}_{2}$ incubator, DMSO solutions of the complexes $1(60 \mu \mathrm{M})$ and $2(5 \mu \mathrm{M})$ were added to the cells, and incubation was continued in dark for $4 \mathrm{~h}$. The medium was subsequently replaced with DPBS, and photo-irradiation was done with visible light of 400-700 nm using the Luzchem photoreactor for $1 \mathrm{~h}$. After irradiation, DPBS was removed and replaced with DMEM containing $10 \%$ FBS, and incubation was continued in the dark for a further period of $24 \mathrm{~h}$. Cells were then trypsinized and collected into $1.5 \mathrm{~mL}$ centrifuge tubes. The cells were washed once with DPBS $(\mathrm{pH}=7.4)$ and fixed by adding $800 \mu \mathrm{L}$ of chilled $70 \%$ methanol dropwise with constant and gentle vortexing to prevent any cell aggregation. The cell suspensions were incubated at $20^{\circ} \mathrm{C}$ for $6 \mathrm{~h}$. The fixed cells were then washed twice with $1.0 \mathrm{~mL}$ of DPBS by centrifuging at $4000 \mathrm{rpm}$ at $4^{\circ} \mathrm{C}$ for $5 \mathrm{~min}$. The supernatants were gently discarded, and the cell pellets were suspended in $200 \mu \mathrm{L}$ of DPBS containing $10 \mathrm{mM} \mathrm{mL}^{-1}$ DNasefree RNase at $37^{\circ} \mathrm{C}$ for $12 \mathrm{~h}$. After digestion of cellular RNA, a $20 \mu \mathrm{L}$ volume of $1.0 \mathrm{mg}$ $\mathrm{mL}^{-1}$ propidium iodide (PI) solution was added to both the mixtures, which were incubated at $25^{\circ} \mathrm{C}$ in the dark for another $20 \mathrm{~min}$. Flow cytometric analysis was performed using a FACS Calibur Becton Dickinson (BD) cell analyzer at FL2 channel (595 nm), and the distribution of cells in various cell cycle phases was determined from the histogram generated by Cell Quest Pro software (BD Biosciences). Data analysis for the percentage of cells in each cell cycle phase was performed by using WinMDI version 2.8.

\subsection{Ethidium bromide/acridine orange dual staining}

The changes in chromatin organization in MCF-7 cells after photo-irradiation were determined after treatment with complexes $\mathbf{1}(60 \mu \mathrm{M})$ and $\mathbf{2}(5 \mu \mathrm{M})$ by dual staining method using acridine orange (AO) and ethidium bromide (EB). About $2 \times 10^{4}$ cells were allowed to adhere overnight on a coverslip placed in each well of a 12 well plate. The cells were treated with the complex for $4 \mathrm{~h}$ in the dark, followed by irradiation with visible light of $400-700 \mathrm{~nm}\left(10 \mathrm{~J} \mathrm{~cm}^{-2}\right)$. Dark controls were also used. The cells were then allowed to recover for $1 \mathrm{~h}$, washed with DPBS, stained with AO/EB mixture $(1: 1,10 \mu \mathrm{M})$ for $15 \mathrm{~min}$. The cover slips were mounted using antifade and observed with a confocal laser scanning microscope (Zeiss LSM 510 apochromat).

\section{Results and Discussion}

\subsection{Synthesis and characterization}

Iron(II) complexes $\left[\mathrm{Fe}(\mathrm{B})_{2}\right] \mathrm{Cl}_{2} \quad(\mathbf{1}$ and $\mathbf{2})$ of two tridentate polypyridyl bases (B), viz. 2-(2-pyridyl)1,10-phenanthroline (pyphen) in $\mathbf{1}$ and 3-(pyridin-2yl)dipyrido[3,2-a:2',3'-c]phenazine (pydppz) in 2 were prepared by a general synthetic procedure in which one equivalent of $\mathrm{FeCl}_{2}$ was reacted with two equivalents of the corresponding base in methanol (figure 1). The complexes were characterized from the analytical and spectral data. Selected physicochemical data are given in table 1. Both the complexes showed good solubility in DMF, DMSO, dichloromethane and chloroform. They were moderately soluble in methanol, ethanol and acetonitrile. The complexes were found to be stable in both solid and solution phases as seen from the UVvisible absorption spectral data which remained unaltered for a period of $24 \mathrm{~h}$. The ESI-MS spectra of the complexes in aqueous methanol showed a single prominent peak corresponding to the molecular ion peak [M$2 \mathrm{Cl}]^{2+}$. The molar conductivity data showed that the complexes are 1:2 electrolytic in aqueous DMF $(\sim 145$ $\mathrm{S} \mathrm{cm}^{2} \mathrm{M}^{-1}$ ). The electronic absorption spectra of the complexes in DMF showed a metal to ligand charge transfer (MLCT) transition near $580 \mathrm{~nm}$. Ligand centred $\pi \rightarrow \pi^{*}$ transition bands were observed near $280 \mathrm{~nm}$ (figure 2). The pydppz complex displayed two additional bands at $390 \mathrm{~nm}$ and $367 \mathrm{~nm}$ assignable to the $n \rightarrow \pi^{*}$ transitions of the phenazine moiety. ${ }^{45}$ The complexes are redox active showing cyclic voltametric responses involving the metal centre and the polypyridyl bases in DMF vs. SCE using 0.1 M TBAP as the supporting electrolyte. Both the complexes show oxidative response near $1.0 \mathrm{~V}$ corresponding to the $\mathrm{Fe}(\mathrm{III})-\mathrm{Fe}(\mathrm{II})$ couple. Quasi-reversible redox responses were observed at $-1.08 \mathrm{~V}$ for $\mathbf{1}$ and $-0.8,-1.13 \mathrm{~V}$ for 2 corresponding to the polypyridyl base. 
Table 1. Physicochemical data and DNA binding parameters for the complexes $\mathbf{1}$ and 2.

\begin{tabular}{lccccc}
\hline Complex & $\lambda(\mathrm{nm})\left(\varepsilon / \mathrm{M}^{-1} \mathrm{~cm}^{-1}\right)^{\mathrm{a}}$ & $\Lambda_{\mathrm{M}}^{\mathrm{b}}\left(\mathrm{S} \mathrm{cm}^{2} \mathrm{M}^{-1}\right)$ & $E^{\mathrm{c}}(\mathrm{V})$ & $K_{\mathrm{b}}^{\mathrm{d}} \times 10^{-6}\left(\mathrm{M}^{-1}\right)[\mathrm{s}]$ & $\Delta T_{\mathrm{m}}^{\mathrm{e}}\left({ }^{\circ} \mathrm{C}\right)$ \\
\hline $\mathbf{1}$ & $580(5200)$ & 145 & 1.01 & $1.1( \pm 0.3)[0.4]$ & 1.0 \\
$\mathbf{2}$ & $556(4250)$ & 142 & 1.0 & $3.4( \pm 0.6)[0.6]$ & 2.7 \\
\hline
\end{tabular}

${ }^{a}$ In DMF. ${ }^{b}$ Molar conductivity value in $20 \%$ aqueous DMF at $25^{\circ} \mathrm{C}$. ${ }^{c}$ Potential vs. SCE in DMF $-0.1 \mathrm{M}$ TBAP at a scan rate of $50 \mathrm{mV} \mathrm{s}^{-1}$. ${ }^{\mathrm{d}}$ Intrinsic binding constant to ct-DNA (MvH eq. fitting parameter) with $10 \mu \mathrm{M}$ complex concentration. ${ }^{\mathrm{e}} \mathrm{Change}$ in the ct-DNA melting temperature in phosphate buffer $(\mathrm{pH}=6.8)$.

\subsection{Theoretical study}

Theoretical calculations were carried out using B3LYP level of DFT (density functional theory) to understand the photophysical and redox properties of the complexes (figure 3). ${ }^{46-49}$ Following the orbital arguments proposed by Amouyal and co-workers, calculations were performed on geometrically modified iron(II) complexes. As expected, considerable d-orbital contribution from the iron was observed in the HOMO and LUMO is found to be localized on the polypyridyl ligand. MLCT having high oscillator strength was found to be operative in both the complexes. The electronic transitions tallied with the theoretical assignments performed using TDDFT calculations.

\subsection{DNA binding studies}

Absorption spectral titration was used to monitor the mode of interaction of the complexes $\mathbf{1}$ and $\mathbf{2}$ with ctDNA (figure 4). The intrinsic equilibrium DNA binding constant $\left(K_{\mathrm{b}}\right)$ values of the complexes are given in table 1 . The $K_{\mathrm{b}}$ values of $\sim 10^{6} \mathrm{M}^{-1}$ follow the order: $\mathbf{2}>\mathbf{1}$. The pydppz complex $\mathbf{2}$ with an extended planar

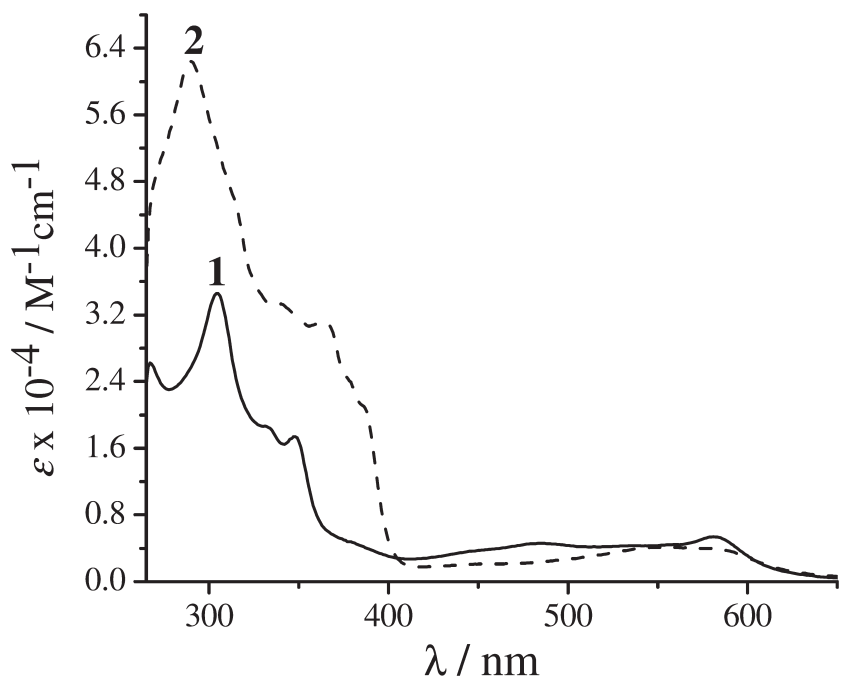

Figure 2. Electronic absorption spectra of the complexes 1 (-) and 2 (- - -) in DMF. aromatic moiety showed higher DNA binding strength than the pyphen analogue $1 .^{50}$ This is in accordance with the recently reported result that extended planarity gives better ability to bind the DNA double helix. ${ }^{51}$ The $K_{\mathrm{b}}$ values indicate partial intercalative DNA binding nature of the complexes.

Thermal denaturation experiments were done to gain insight into the stability of the DNA double helix upon binding to $\mathbf{1}$ and $\mathbf{2}$ (figure 5a). A small positive shift of the DNA melting temperature $\left(\Delta T_{\mathrm{m}}\right)$ was observed upon addition of complex 1 to ct-DNA. The moderate $\Delta T_{\mathrm{m}}$ value suggests primarily groove binding nature of the complex to ct-DNA in preference to an intercalative mode of binding that normally results in large positive $\Delta T_{\mathrm{m}}$ value. ${ }^{52,53}$ The $\Delta T_{\mathrm{m}}$ value for the pydppz complex $\mathbf{2}$ is higher than that of the pyphen complex 1. It is apparent from the data that the extended aromatic rings are involved in the binding to ct-DNA. Viscosity measurements were carried out to examine the effect of the complexes on the specific relative viscosity of DNA (figure 5b). The relative specific viscosity $\eta / \eta_{0}$ ( $\eta$ and $\eta_{0}$ are the specific viscosities of DNA in the presence and absence of the complexes, respectively) of DNA is a measure of the increase in contour length associated with the separation of DNA base pairs caused by intercalation. A classical DNA intercalator like ethidium bromide shows a significant increase in the viscosity of the DNA solutions. In contrast, a partially intercalated DNA complex would result in less pronounced effect on the viscosity. ${ }^{54}$ The groove binder Hoechst 33258 was used as a reference compound that showed insignificant increase in viscosity. While the viscosity profile of the pydppz complex $\mathbf{2}$ is similar to that of EB indicating partial DNA intercalative mode of binding of the pydppz complex, the viscosity profile of the pyphen complex $\mathbf{1}$ is suggestive of DNA groove binding. ${ }^{55}$

\subsection{MTT Assay}

The photocytotoxicity of complexes $\mathbf{1}$ and $\mathbf{2}$ was studied in breast cancer cell line MCF-7 and keratinocyte $\mathrm{HaCaT}$ cells by MTT assay. The complexes upon prior 


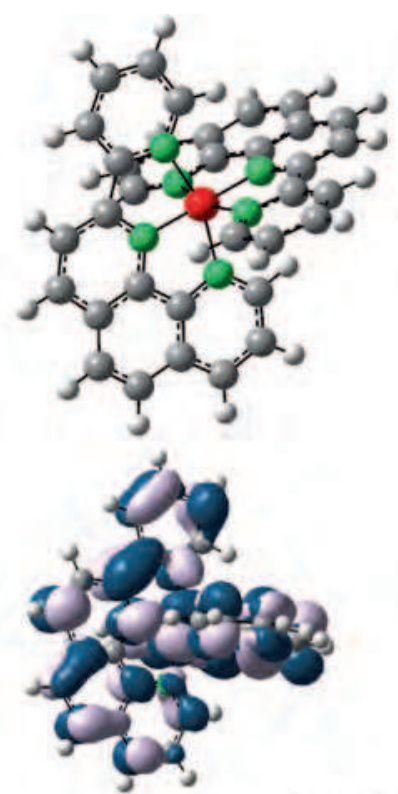

LUMO

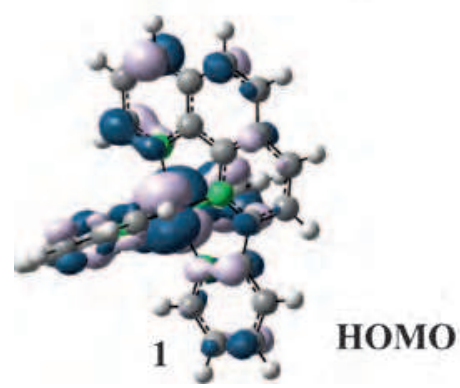

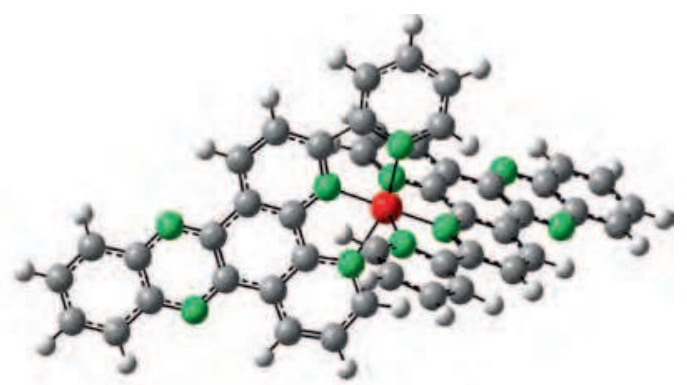

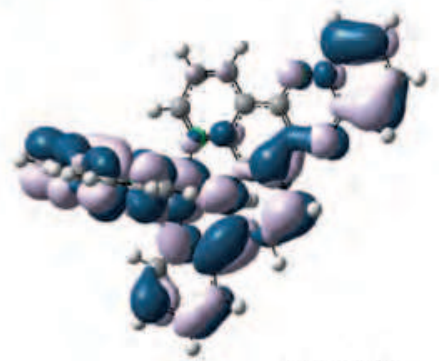

LUMO

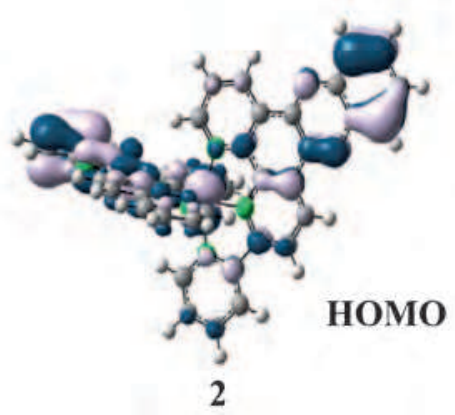

Figure 3. The energy optimized structures of complexes $\mathbf{1}$ and $\mathbf{2}$ along with the FMOs.

incubation for $4 \mathrm{~h}$ in dark and subsequent photoexposure to visible light of 400-700 $\mathrm{nm}$ for $1 \mathrm{~h}$ showed a dose dependent decrease in cell viability with an $\mathrm{IC}_{50}$

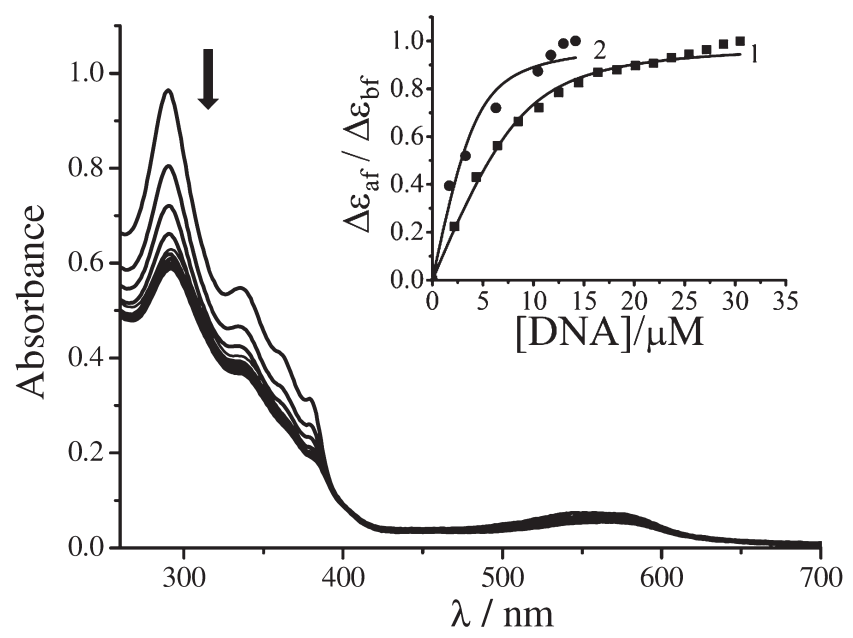

Figure 4. Absorption spectral traces of complex 2 in $5 \mathrm{mM}$ Tris- $\mathrm{HCl}$ buffer $(\mathrm{pH}$ 7.2) on increasing the quantity of ct-DNA. The inset shows the $\mathrm{MvH}$ fitting for the complexes 1 and 2. value of complex 2 being $0.08( \pm 0.01) \mu \mathrm{M}$ for HaCaT and $13.1( \pm 1.0) \mu \mathrm{M}$ for MCF-7 cells (figure 6). The cells unexposed to light gave an $\mathrm{IC}_{50}$ value of $6.8 \mu \mathrm{M}$ for $\mathrm{HaCaT}$ and $>100 \mu \mathrm{M}$ for MCF-7 indicating low dark toxicity in MCF-7 cell line but moderate dark toxicity in $\mathrm{HaCaT}$ cell line. Complex $\mathbf{1}$ gave an $\mathrm{IC}_{50}$ value of 51.3 $( \pm 1.1) \mu \mathrm{M}$ upon exposure to visible light of $400-700 \mathrm{~nm}$ and $>100 \mu \mathrm{M}$ in dark in MCF-7 cell line. Complex $\mathbf{2}$ with better photosensitizing ability showed greater photocytotoxicity in cancer cells like MCF-7 as compared to complex $\mathbf{1}$. However, complex $\mathbf{2}$ did not show any significant photocytotoxic effect in non-cancerous cell line HaCaT.

\subsection{DCFDA Assay}

DCFDA assay was done to detect formation of any cellular ROS. Cell permeable DCFDA on oxidation by cellular ROS generates the fluorescent product DCF, with an emission maximum at $525 \mathrm{~nm}$ which can be detected by flow cytometry analysis. A substantial positive shift in the fluorescence (indicating ROS generation) was 


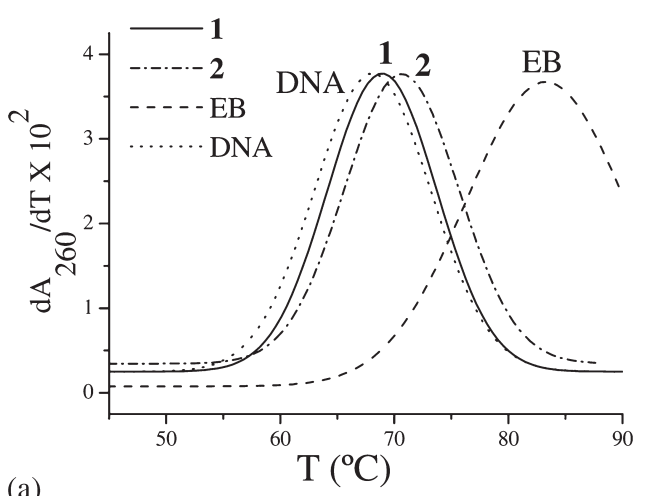

(a)

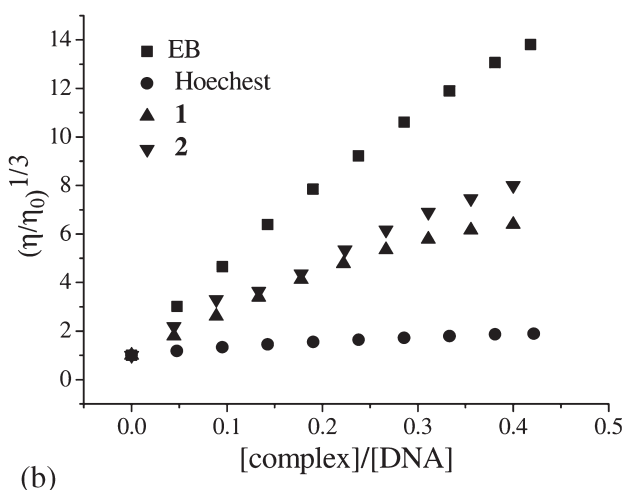

Figure 5. (a) Thermal denaturation plots of $200 \mu \mathrm{M}$ ct-DNA alone and on addition of the complexes 1 and 2; (b) Effect of increasing the concentration of the complexes $\mathbf{1}(\mathbf{\Delta}), \mathbf{2}(\boldsymbol{\nabla})$, ethidium bromide (EB, $\square)$ and Hoechst $33258(\bullet)$ on the relative viscosities of $150 \mu \mathrm{M}$ ctDNA in $5 \mathrm{mM}$ Tris- $\mathrm{HCl}$ buffer at $37.0( \pm 0.1){ }^{\circ} \mathrm{C}$.

observed for MCF-7 cells treated with complexes 1 and 2 upon irradiation with visible light of $400-700 \mathrm{~nm}$ compared to dark and the untreated cells (figure 7a).

\subsection{Cell cycle analysis}

To examine the role of the complexes in the cell cycle, the DNA content of MCF-7 cells treated with complexes $\mathbf{1}$ and $\mathbf{2}$ was measured using a fluorescent dye, viz. propidium iodide (PI) by flow cytometry (figure $7 \mathrm{~b}$ ). The experiments were performed under both light and dark conditions. The complexes in dark did not induce any significant change $(<10 \%)$ in the sub-G1 population (which indicates cell death) of the cells. Complex $\mathbf{1}$ on photo-irradiation stimulated modest cell death $(\sim 10 \%)$. However, under identical experimental conditions, complex 2 showed a marked increase in the sub-G1 population $(\sim 25 \%)$. These data

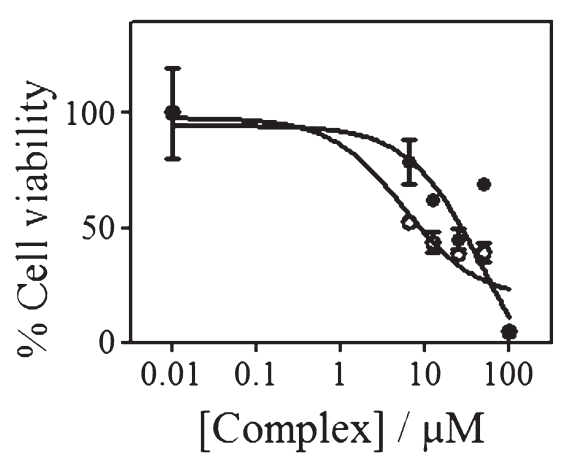

(a)

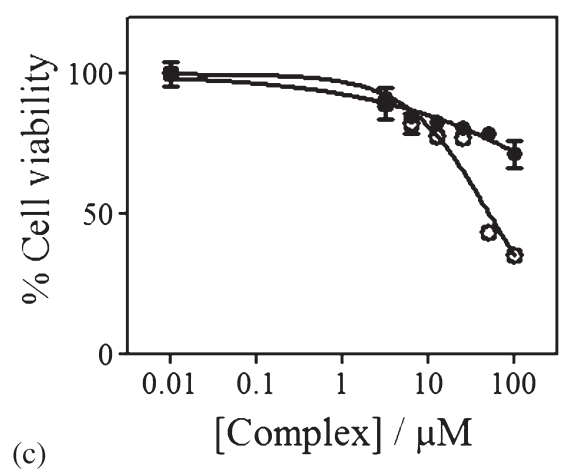

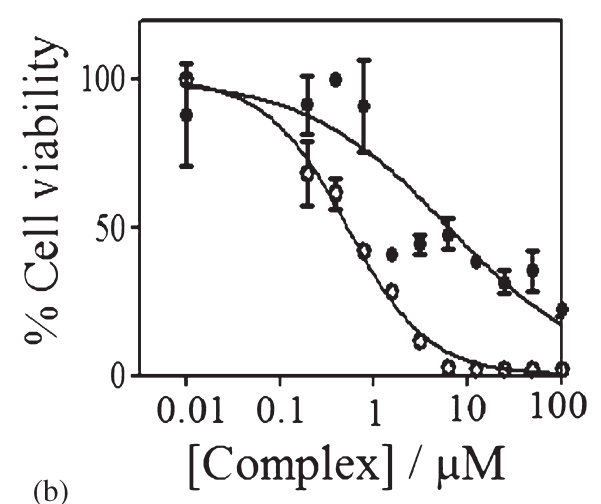

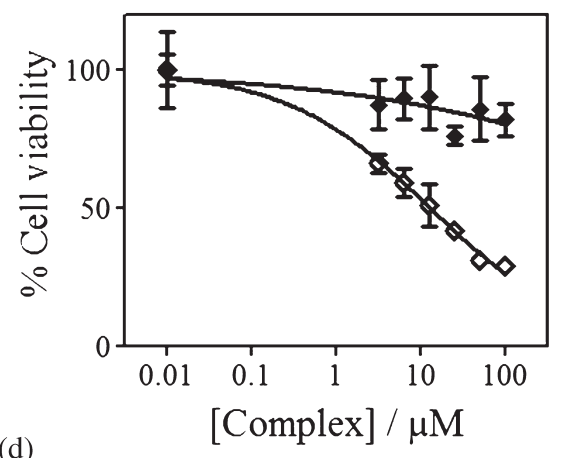

(d)

Figure 6. Photocytotoxicity of the complexes $\mathbf{1}$ and $\mathbf{2}$ in $\operatorname{HaCaT}[(\mathrm{a})$ and (b)] and in MCF-7 [(c) and (d)] cells on $4 \mathrm{~h}$ incubation in dark followed by exposure to light of $400-700 \mathrm{~nm}\left(10 \mathrm{~J} \mathrm{~cm}^{-2}\right)$. 


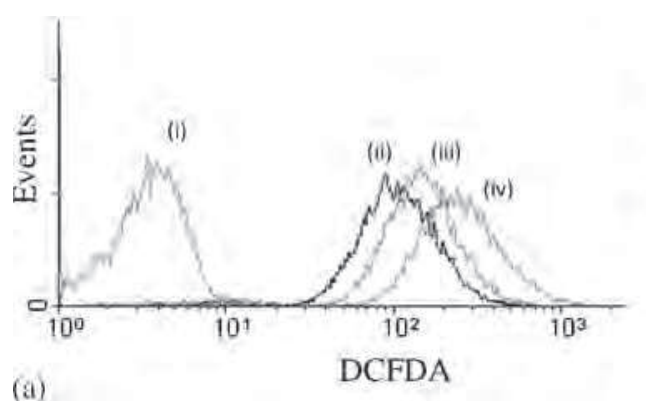

(a)

Figure 7. (a) DCFDA assay for generation of ROS in MCF7 upon exposure of visible light: (i) the fluorescence of cells alone, (ii) the fluorescence of cells + DCFDA, (iii) the fluorescence of cells + DCFDA $+\mathbf{2}$ in dark, and (iv) the fluorescence of cells + DCFDA +2 in light. (b) Cell cycle profile (sub-G1, G1, S, and G2/M phases) of the MCF-7 cells treated with complexes $1(60 \mu \mathrm{M})$ and $2(5 \mu \mathrm{M})$ in dark and after irradiation with visible light $\left(400-700 \mathrm{~nm}, 10 \mathrm{~J} \mathrm{~cm}^{-2}\right)$.

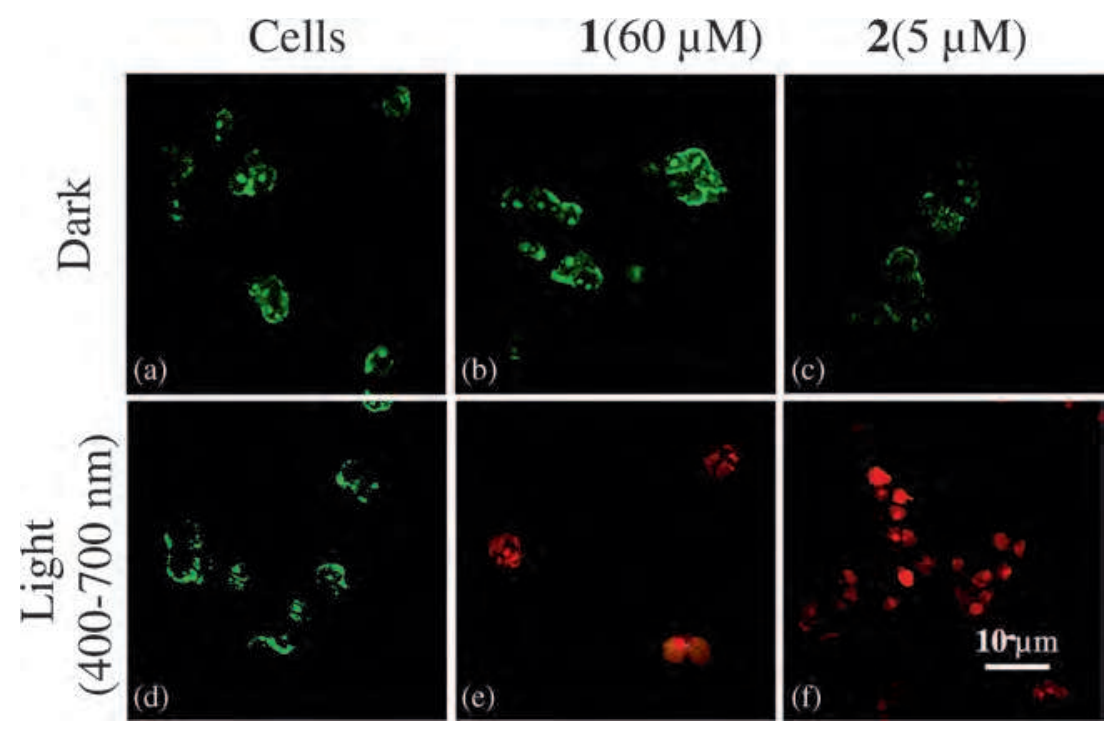

Figure 8. Confocal microscopy images of $\mathrm{MCF}-7$ cell line upon AO/EB staining: panels (a) and (d) correspond to untreated cells in dark and light (400 $-700 \mathrm{~nm})$, panels (b) and (e) show cells treated with $1(60 \mu \mathrm{M})$ in dark and light (400-700 nm) and panels (c) and (f) show cells treated with $2(5 \mu \mathrm{M})$ in dark and light (400-700 $\mathrm{nm})$. Scale bar corresponds to $10 \mu \mathrm{m}$. are in agreement with the photocytotoxicity data of the complexes.

\subsection{Ethidium bromide/acridine orange dual staining}

$\mathrm{EB} / \mathrm{AO}$ dual staining experiment was performed in MCF-7 cells using complexes $\mathbf{1}$ and $\mathbf{2}$ to further investigate their ability to induce any cell death by apoptosis. The experiment was based on the discrimination of live cells from the dead cells on the basis of membrane integrity. AO, which can pass through the plasma membrane, stains the live cells and fluoresces green. EB on the other hand is excluded from the cells having intact plasma membrane and stains only the dead cells, showing orange fluorescence. The cells incubated with the complexes $1(60 \mu \mathrm{M})$ and $2(5 \mu \mathrm{M})$ for $4 \mathrm{~h}$ and irradiated with visible light (400-700 nm, $10 \mathrm{~J} \mathrm{~cm}^{-2}$ ) showed significant reddish orange emission characteristic of the apoptotic cells (figure 8). The controls incubated in dark displayed prominent green emission.

\section{Conclusions}

Iron(II) complex having planar pyridyldipyridophenazine base showed remarkable PDT effect in visible light with low dark toxicity in cancer cell. The pyphen and pydppz complexes are efficient binders to ct-DNA showing partial DNA intercalative binding. 
The results obtained from dual staining using acridine orange and ethidium bromide suggest apoptotic mode of cell death. The results showing the low-spin diamagnetic iron(II) complexes as non-toxic in dark and significantly cytotoxic in light are of importance considering their paramagnetic iron(III) and high-spin iron(II) analogues are known to show significant dark cellular toxicity. ${ }^{31}$

\section{Supplementary Information}

All additional information pertaining to characterization of the complexes using ESI-MS technique (figures S1, S2), IR spectra (figures S3, S4), cyclic voltammograms (figures S5, S6), electronic spectra (figures S7, S8), TDDFT data (table S1) and atomic coordinates for the energy minimized structures (tables S2, S3) are available at www.ias.ac.in/chemsci.

\section{Acknowledgements}

We thank the Department of Science and Technology (DST), Government of India, and the Council of Scientific and Industrial Research (CSIR), New Delhi, for financial support (SR/S5/MBD-02/2007 and 01 (2559)/12/EMR-II). ARC thanks the DST for the J.C. Bose national fellowship and the Alexander von Humboldt Foundation, Germany, for donation of an electrochemical system. We thank Ms. Deepti Bapat for the confocal microscopy images, Ms. Kavya A and Mr. Vashisht $\mathrm{K}$ for the FACS data, Dr. Tirtha Mukherjee and Mr. ChinnaAyya Swamy P for DFT calculations.

\section{References}

1. Ethirajan M, Chen Y, Joshi P and Pandey R K 2011 Chem. Soc. Rev. 40340

2. Bonnett R 2000 In Chemical Aspects of Photodynamic Therapy (London: Gordon \& Breach)

3. Henderson B W, Busch T M, Vaughan L A, Frawley N P, Babich D, Sosa T A, Zollo J D, Dee A S, Cooper M T, Bellnier D A, Greco W R and Oseroff A R 2000 Cancer Res. 60525

4. Dolmans D E J G J, Fukumura D and Jain R K 2003 Nat. Rev. 3380

5. Sessler J L and Miller R A 2000 Biochem. Pharmacol. 59733

6. Burrows C J and Muller J G 1998 Chem. Rev. 981109

7. Szacilowski K, Macyk W, Drzewiecka-Matuszek A, Brindell M and Stochel G 2005 Chem. Rev. 1052647

8. Moriwaki S I, Misawa J, Yoshinari Y, Yamada I, Takigawa M and Tokura Y 2001 Photodermatol. Photoimmunol. Photomed. 17241

9. Ochsner M 1996 J. Photochem. Photobiol. B: Biology 323
10. Crespy D, Landfester K, Schubert U S and Schiller A 2010 Chem. Commun. 466651

11. Farrer N J, Salassa L and Sadler P J 2009 Dalton Trans. 10690

12. Ostrowski A D and Ford P C 2009 Dalton Trans. 10660

13. Ford P C 2009 J. Am. Chem. Soc. 13115963

14. Chifotides H T and Dunbar K R 2005 Acc. Chem. Res. 38146

15. Schatzschneider U 2010 Eur. J. Inorg. Chem. 1451

16. Gasser G, Ott I and Nolte N M 2011 J. Med. Chem. 543

17. Boerner L J K and Zaleski J M 2005 Curr. Opin. Chem. Biol. 9135

18. Fry N L and Mascharak P K 2011 Acc. Chem. Res. 44 289

19. Smith N A and Sadler P J 2013 Philos. Trans. R. Soc. A 37120120519

20. Chakravarty A R and Roy M 2012 Prog. Inorg. Chem. 57119

21. Basu U, Khan I, Hussain A, Gole B, Kondaiah P and Chakravarty A R 2014 Inorg. Chem. 532152

22. Banerjee S, Dixit A, Shridharan R N, Karande A A and Chakravarty A R 2014 Chem. Commun. 505590

23. Basu U, Khan I, Hussain A, Kondaiah P and Chakravarty A R 2012 Angew. Chem. Int. Ed. 51 2658

24. Mackay F S, Woods J A, Heringová P, Kašpárková J, Pizarro A M, Moggach S A, Parsons S, BrabecV and Sadler P J 2007 Proc. Natl. Acad. Sci.USA 10420743

25. Kolishetti N, Dhar S, Valencia P, Lin L, Karnik R, Lippard S J, Langer R and Farokhzad O C 2010 Proc. Natl. Acad. Sci. U. S. A. 10717939

26. Dhar S, Daniel W L, Giljohann D A, Mirkin C A and Lippard S J 2009 J. Am. Chem. Soc. 13114652

27. Umezawa Y, Morishima H, Saito S, Takita T, Umezawa H, Kobayashi S, Otsuka M, Narita M and Ohno M 1980 J. Am. Chem. Soc. 1026630

28. Burger R M 1998 Chem. Rev. 981153

29. Kraft B J and Zaleski J M 2001 New J. Chem. 25 1281

30. Garai A, Basu U, Khan I, Pant I, Hussain A, Kondiah P and Chakravatry A R 2014 Polyhedron 73124

31. Wong E L M, Fang G S, Che C M and Zhu N 2005 Chem. Commun. 4578

32. Hertzberg R P and Dervan P B 1982 J. Am. Chem. Soc. 104313

33. Roelfes G, Lubben M, Leppard S W, Schudde E P, Hermant R M, Hage R, Wilkinson E C, Que Jr. L and Feringa B L 1997 J. Mol. Catal. A 117223

34. Loeb K E, Zaleski J M, Westre T E, Guajardo R J, Mascharak P K, Hedman B, Hodgson K O and Solomon E I 1995 J. Am. Chem. Soc. 1174545

35. Perrin D D, Armarego W L F and Perrin D R 1980 In Purification of Laboratory Chemicals (Pergamon Press: Oxford)

36. Dickeson J E and Summers L A 1970 Aus. J. Chem. 23 1023

37. Collins J G, Sleeman A D, Aldrich-Wright J R, Greguric I and Hambley T W 1998 Inorg. Chem. 373133

38. Amouyal E, Homsi A, Chambron J C and Sauvage J P 1990 J. Chem. Soc. Dalton Trans. 1841

39. Reichmann M E, Rice S A, Thomas C A and Doty P 1954 J. Am. Chem. Soc. 763047 
40. McGhee J D and von Hippel P H 1974 J. Mol. Biol. 86 469

41. Carter M T, Rodriguez M and Bard A J 1989 J. Am. Chem. Soc. 1118901

42. Mosmann T 1983 J. Immunol. Methods 6555

43. Keston A S and Brandt R 1965 Anal. Biochem.11 1

44. Takanashi T, Ogura Y, Taguchi H, Hashizoe M and Honda Y I 1997 Ophthalmol. Visual. Sci. 382721

45. Toshima K, Takano R, Ozawa T and Matsumura S 2002 Chem. Commun. 212

46. BeckeA D 1998 Phys. Rev. A 383098

47. BeckeA D 1993 J. Chem. Phys. 985648

48. Lee C, Yang W and Parr R G 1988 Phys. Rev. B 37 785

49. Hay P J and Wadt W R 1985 J. Chem. Phys. 82284
50. Phillips T, Haq I, Meijer A J H M, Adams H, Soutar I, Swanson L, Sykes M J and Thomas J A 2004 Biochemistry 4313657

51. (a) Ramakrishnan S, Suresh E, Riyasdeen A, Akbarsha M A and Palaniandavar M 2011 Dalton Trans. 40 3524; (b) Banerjee S, Hussain A, Prasad P, Khan I, Banik B, Kondaiah P and Chakravarty A R 2012 Eur. J. Inorg. Chem. 3899

52. An Y, Liu S-D, Deng S-Y, Ji L-N and Mao Z-W 2006 J. Inorg. Biochem. 1001586

53. Gunther L E and Yong A S 1968 J. Am. Chem. Soc. 90 7323

54. Veal J M and Rill R L 1991 Biochemistry 301132

55. Pellegrini P P and Aldrich-Wright J R 2003 Dalton Trans. 176 